OPEN ACCESS

Edited by:

Satoshi Sekiguchi,

University of Miyazaki, Japan

Reviewed by:

Ayako Miyazaki,

National Agriculture and Food

Research Organization, Japan

Tomoko Tajima,

Osaka Prefecture University, Japan

${ }^{*}$ Correspondence:

Hyunil Kim

hikim@optipharm.co.kr

Specialty section:

This article was submitted to

Veterinary Infectious Diseases,

a section of the journal

Frontiers in Veterinary Science

Received: 22 July 2020 Accepted: 30 September 2020

Published: 28 October 2020

Citation:

Wang $\mathrm{H}-\mathrm{y}$, Song JK, Shin S, Choi KM and Kim H (2020) One-Tube Nested

Real-Time PCR Assay for Rapid Screening of Porcine Cytomegalovirus in Clinical Samples.

Front. Vet. Sci. 7:586045. doi: 10.3389/fvets.2020.586045

\section{One-Tube Nested Real-Time PCR Assay for Rapid Screening of Porcine Cytomegalovirus in Clinical Samples}

\author{
Hye-young Wang ${ }^{1}$, Joong Ki Song ${ }^{2}$, Seongho Shin ${ }^{2}$, Ki Myung Choi ${ }^{1}$ and Hyunil Kim ${ }^{1 *}$ \\ ${ }^{1}$ Optipharm, Inc., Cheongju, South Korea, ${ }^{2}$ Optipharm Animal Disease Diagnostic Center, Cheongju, South Korea
}

Porcine cytomegalovirus (PCMV) is a pathogen that must be removed from pigs for use as organ donors in xenotransplantation. Recently, it has been found that when donor pigs are infected with PCMV, a pig-to-non-human-primate xenotransplantation lower transplant survival by 2-3 times. Therefore, highly sensitive methods are needed to maintain designated pathogen free (DPF) pig and screen for xenografts. The purpose of this study was to evaluate the performance of commercially available method with one-tube nested real-time PCR assay to quickly detect PCMV infection in clinical samples and compare the results with those of sequence analysis. Molecular diagnostic methods were used to evaluate 127 samples, including tissues and blood samples from pigs suspected of PCMV infection. The detection rate for positive PCMV was 38.6\% ( $n=49)$, 23.6\% $(n=30)$, and $12.6 \%(n=16)$ in one-tube nested real-time PCR, nested PCR, and conventional PCR methods, respectively. All PCMV-positive samples in conventional PCR or nested PCR methods were also positive in the one-tube nested real-time PCR assay. All the PCR products in the three methods were checked for amplification of PCMV gene by PCR and subsequent direct sequencing. The results of one-tube nested real-time PCR were found to be consistent with those of sequence analysis for all the samples and showed good agreement $(\kappa=1)$. Our study found that the one-tube nested real-time PCR assay is more sensitive than the other two methods. This assay required approximately $1.5 \mathrm{~h}$ for completion. Therefore, we concluded that one-tube nested real-time PCR assay is a fast and reliable method for the characterizing pathogen responsible for PCMV infection.

Keywords: porcine cytomegalovirus, one-tube nested real-time PCR, xenotransplantation, designated pathogen free pig, diagnosis

\section{INTRODUCTION}

In order to alleviate the shortage of human donor organs available for allograft, xenotransplantation using pig cells, tissues, or organs have been proposed (1-3). This may be related to the transmission of porcine mediated disease, so the maintenance of designated pathogen free pigs is required for xenotransplantation (4-6).

Porcine cytomegalovirus (PCMV), also known as Suid herpesvirus 2 (SuHV2), is an enveloped virus with a double-stranded linear DNA genome. PCMV can cause fever, reduced general condition, loss of appetite, numbness, neurological signs, and respiratory symptoms (e.g., sneezing, 
coughing, and dyspnea), acute to subacute disease, and high mortality and morbidity in piglets $(3,7)$. In a previous studies, the virus have been reported to be immunosuppressive pathogen primarily affecting the immune function of the macrophages and $\mathrm{T}$ lymphocytes, which can cause preclinical infection in adult pigs and reproductive failure in pregnant sows $(7,8)$. PCMV infection is widespread worldwide and has a high prevalence in swine herds. For this reason, many researchers have continued to pay attention to the potential risk to public health in interspecies transmission of PCMV and human xenotransplantation (7). In addition, international xenotransplantation association has a guideline that resource pig for xenotransplantation should be free from PCMV (9). These data indicate that it is essential to quickly detect PCMV infection with high sensitivity and specificity in the early stages of the resource swine herds.

So far, some molecular diagnostic methods, including polymerase chain reaction (PCR) (10-12), enzyme-linked immunosorbent assay (ELISA) (13, 14), loop-mediated isothermal amplification assay (LAMP) (15), and western blot analysis (16) for the detection of PCMV infection has been reported. These assays have low sensitivity, need to agarose gel analysis for amplification products, or have a risk of contamination, which can lead to incorrect results. In addition, companies such as Novateinbio and MyBioSource have ELISA products that detect antibody or antigen of PCMV, there are no commercialized products using molecular diagnostic methods until now. Real-time fluorescent quantitative PCR technology has become a powerful alternative platform for detection and differentiation of pathogenic viruses $(3,17,18)$.

In this study, we developed a highly sensitive one-tube nested real-time PCR assay (Opti PCMV-qPCR; Optipharm, Osong, Republic of Korea) that combines nested PCR and real-time PCR to detect PCMV targeting DNA polymerase gene and consists of two sequential reactions in a single tube. The performance of the one-tube nested real-time PCR assay was evaluated using clinical samples suspected of PCMV compared to conventional PCR and nested PCR, and the results were confirmed by sequence analysis.

\section{METHODS}

\section{Preparation of DNA Samples}

To evaluate the diagnostic performance of the PCR, nested PCR, and one-tube nested real-time PCR methods, a total of 127 field samples, including 37 lung tissues, 30 blood samples, 30 serums, and 30 feces samples, were provided by the Optipharm Animal Disease Diagnostic Center, which was commissioned from January to December 2019. In addition, 10 organs (lung, liver, pancreas, spleen, kidney, brain, heart, small intestine, nasal concha, and tonsil) of six pigs were analyzed to determine the infection rate of PCMV for each organ by one-tube nested real-time PCR assay. According to the manufacturer's recommendation, DNA was extracted from $200 \mu \mathrm{L}$ of serum or $20 \mathrm{mg}$ of organ tissue homogenate using a commercial automated system (Miracle-AutoXT Automated Nucleic Acid Extraction System, Intronbio, Seongnam, Republic of Korea). To avoid crosscontamination, all samples were individually processed and stored at $-20^{\circ} \mathrm{C}$. The content and purity of the extracted DNA was analyzed by measuring the absorbance at 260 and $280 \mathrm{~nm}$ by a spectrophotometer (Infinite 200 NanoQuant; Tecan, Switzerland).

\section{Conventional PCR and Nested PCR}

To evaluate the usefulness of one-tube nested real-time PCR assay, the results of conventional PCR and nested PCR were compared. PCR primers for the conventional PCR and nested PCR used in this study were selected from the nucleotide sequence of the PCMV DNA polymerase gene determined by Hamel (10) and Fryer (11), respectively. PCR was performed using $20 \mu \mathrm{L}$ of reaction mixture (Genetbio, Daejeon, Korea) containing $2 \times$ master mix, $1 \times$ primer mixture, $3 \mu \mathrm{L}$ of sample DNA, and $\mathrm{ddH}_{2} \mathrm{O}$ added to achieve a final volume of 20 $\mu \mathrm{L}$. The reaction conditions for conventional PCR and nested PCR using the outer primers (PCMVF1 and PCMVR1) were as follows: pre-denaturation at $94^{\circ} \mathrm{C}$ for $5 \mathrm{~min}$; 40 cycles of $94^{\circ} \mathrm{C}$ for $30 \mathrm{~s}, 60^{\circ} \mathrm{C}$ for $30 \mathrm{~s}, 72^{\circ} \mathrm{C}$ for $30 \mathrm{~s}$; and a final extension at $72^{\circ} \mathrm{C}$ for $10 \mathrm{~min}$. For nested PCR using the inner primers (PCMVFB and PCMVR2), two microliters of the first-round PCR mixture was transferred to $20 \mu \mathrm{l}$ of a premixed solution containing the PCR reagents at the same concentrations listed above. The amplification procedure was repeated for 40 cycles with the same time and temperature parameters as described above, except that annealing at $55^{\circ} \mathrm{C}$ for $30 \mathrm{~s}$ was used. The amplified target was visualized as a single band corresponding to a length of 413-bp for conventional PCR and 160-bp for nested PCR using the Chemi Doc system (Vilber Lourmat, Deutschland, Germany).

\section{One-Tube Nested Real-Time PCR Assay}

Oligonucleotide primers and probes corresponding to the two strands of the DNA polymerase gene of PCMV (Figure 1) were designed using Primer3Plus (http://www.bioinformatics.nl/ cgi-bin/primer3plus/primer3plus.cgi). Primers were prepared as probes corresponding to the complementary strands and used exclusively thereafter. To verify the efficiency of the selected primers and probe, synthesized a positive control DNA sample (Bioneer, Daejeon, Republic of Korea) and amplified with custom PCR primers (forward, $5^{\prime}$-ATGACATTCTTAATCCATATAT- $3^{\prime}$ and reverse, 5'-CACTGTCCCTAAAACTACTG-3') resulting in amplicons of 3,010 bp. The resulting product was mutagenized after subcloning with pBHA vector. Detection of PCMV in clinical samples was performed with Opti PCMV real-time PCR (Optipharm), a quantitative one-tube nested real-time PCR-based assay, using a CFX-96 real-time PCR system (BioRad, Hercules, CA, USA) for thermal cycling and fluorescence detection. Real-time PCR amplification was performed in a total reaction volume of $20 \mu \mathrm{L}$ containing $10 \mu \mathrm{L}$ of $2 \times$ Thunderbird probe qPCR mix (Toyobo, Osaka, Japan), $2.5 \mu \mathrm{L}$ of a mixture of 5 pmol each primers and 5 pmol TaqMan probe that were labeled with fluorophores (FAM-BHQ1), and $3 \mu \mathrm{L}$ template DNA. The real-time PCR kit consisted of an internal control (IC) DNA and a primer set for IC DNA amplification included in the reaction mixture, which was used to indicate successful nucleic acid extraction, sample quality, and to confirm 


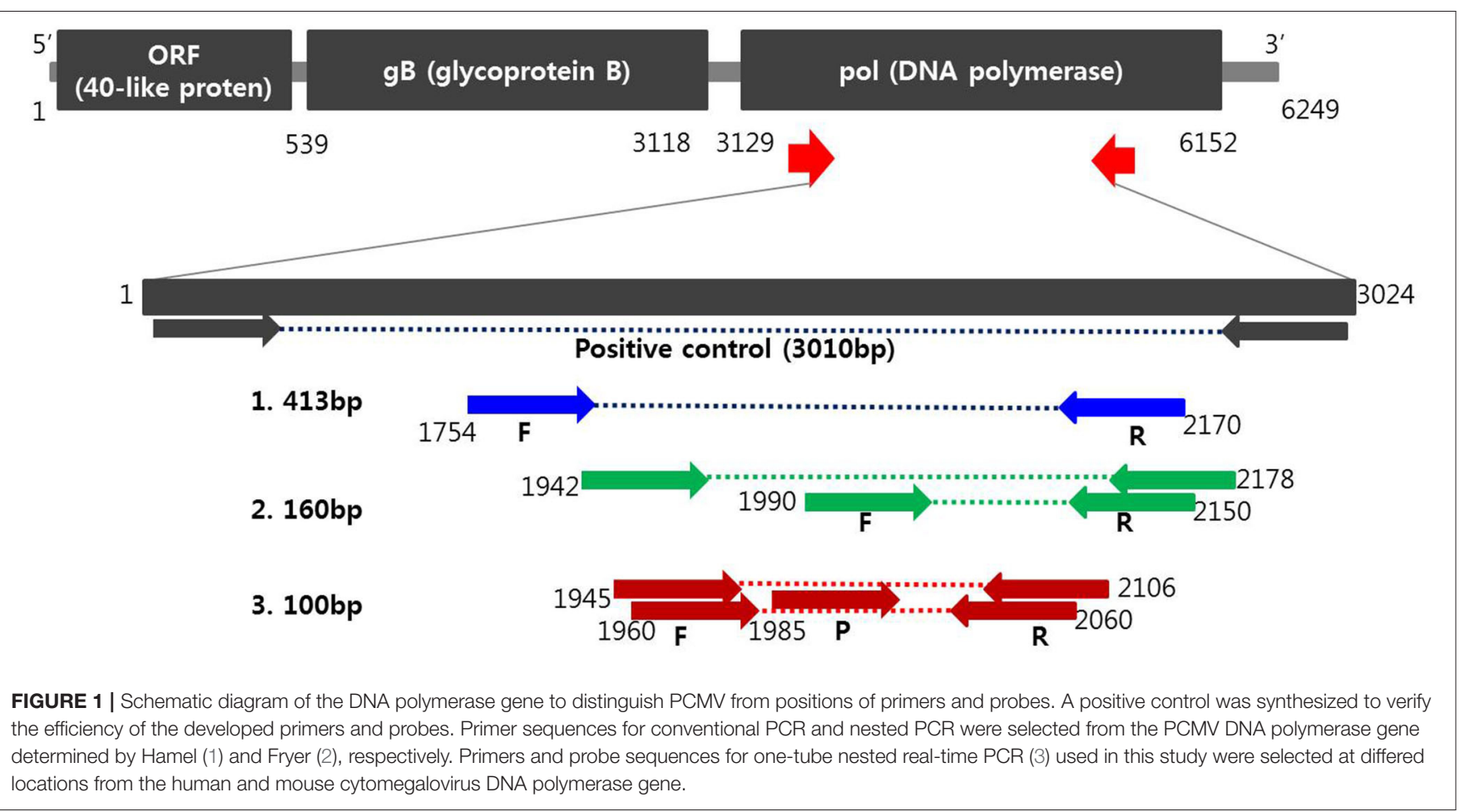

the presence of PCR inhibitors in the reaction. Therefore, it does not compete directly with the amplification of speciesspecific targets in multiplex real-time PCR. Positive (plasmid PCMV DNA) and negative controls consisting of molecular grade (DNAse/RNAse-free) water (Ultra pure water; Welgene, Gyeongsan, Republic of Korea) without template DNA were included in each assay. The assay was carried out under the following conditions: $95^{\circ} \mathrm{C}$ for $3 \mathrm{~min}$, then 10 cycles of $3 \mathrm{~s}$ at $95^{\circ} \mathrm{C}$ and $30 \mathrm{~s}$ at $60^{\circ} \mathrm{C}$, and then by 40 cycles of $3 \mathrm{~s}$ at $95^{\circ} \mathrm{C}$ and $30 \mathrm{~s}$ at $55^{\circ} \mathrm{C}$. Each sample was tested in duplicate by running the PCR cycle twice and a positive result was obtained when the $C_{T}$ value was $<35$.

\section{Interfering Reactions and Reproducibility Analysis}

For interfering reactions, we used the following 7 substances by concentration: EDTA and sodium citrate (1, 10, 20, and $50 \mathrm{mM})$, and heparin $(250,300,375$, and $500 \mathrm{IU})$ for anticoagulants, phosphate buffered saline (PBS; 1, 5, 10, and 20X) for tissue emulsion, EtOH and xylene (1, 5, 10, 20, and 50\%), and blood (1, 5, and 10\%). The repeatability and reproducibility of this assay were performed with a total of 240 tests $(10$ days $\times 2$ runs/day $\times 4$ replicates $\times 3$ lots). The coefficient of variation $(\mathrm{CV})$ was calculated according to the form of the mean $\mathrm{C}_{\mathrm{T}}$ values/standard deviation (SD).

\section{Sequence Analysis}

To confirm the results of the three molecular diagnostic methods, PCR amplicons of all clinical isolates were sequenced using an ABI 3730 automated DNA sequencer (Applied Biosystems, Foster City, CA, USA) and the ABI Prism BigDye Terminator (Applied Biosystems) system (CosmoGenetech, Republic of Korea). The primer sets used to amplify the target DNA polymerase gene were $5^{\prime}$ CCTGATCTTAAATGACGAGGACGTGAC-3' (413F) and 5'-ACCGTCTGAGAGACTGAACTTCTCTGACAC-3' (413R), 5'-AGGACCCTATGTTGGCAYTGATAC-3' (1945F) and 5'TCGTCTGCCTRAGCATGTCC-3' (2106R), which resulted in a 413-bp and 162-bp PCR product, respectively. The obtained sequence was compared with that of the National Center for Biotechnology Information GenBank database. The primer sequences had been removed from alignment sequences before phylogenetic analysis. Multiple alignments of nucleotide sequences based on the PCR product of the PCMV DNA polymerase gene mentioned above were performed using MUSCLE within the Phylogeny.fr software (19). Then, Gblocks was used as a collection method to align the sequences, assess the phylogenetic relationships by the PhyML using the 49 strains isolated in this study, together with 12 PCMV strains deposited in the GenBank database, and finally visualized the phylogenetic tree by TreeDyn.

\section{RESULTS}

\section{Analytical Sensitivity and Specificity of One-Tube Nested Real-Time PCR}

The analytical sensitivity of the assay for PCMV detection was determined using a standard curve that 10 -fold serially diluted $\left(10^{6}\right.$ copies -1 copy) of plasmid DNA containing cloned PCMV 
gene (Figure 2). The sensitivity was estimated as the lowest PCMV gene copies yielding a positive result in all 20 replicates, and the corresponding $\mathrm{C}_{\mathrm{T}}$ value were selected as the analysis cutoff. A standard curve was generated by plotting the log quantity of PCMV DNA vs. the corresponding $\mathrm{C}_{\mathrm{T}}$ value, and the coefficient of determination $\left(R^{2}\right)$ for linear regression was 0.997 with a slope of -4.082 . The detection limit of the one-tube nested real-time PCR assay for PCMV was detected at a concentration of 1 copy per reaction. The $\mathrm{C}_{\mathrm{T}}$ values of PCMV DNA concentration ranged from 1.2 to 28.5 , and mean $\mathrm{C}_{\mathrm{T}}$ values were $2.1 \pm 2.2(95 \%$ confidence interval [CI], 1.2-3) to $27.1 \pm 1.7$ (95\% CI, 26.4-27.8) and the $\mathrm{CV}$ was $<3 \%$.

To assess the potential cross-reactivity, analytical specificity was performed with 40 samples with concentrations above $10^{4}$ copies of individual bacterial/viral genes. The one-tube nested real-time PCR assay to detect PCMV-positive showed negative results in all strains except control PCMV. Hence, these primers and probes did not react with any bacterial and viral strains (Table 1).

\section{Results of Interfering Reactions and Reproducibility Analysis by One-Tube Nested Real-Time PCR}

We performed the interference reaction with 7 substances by concentration. As a result, there was no interference below $50 \mathrm{mM}$ EDTA, $50 \mathrm{mM}$ sodium, 375IU heparin, 10X PBS, 50\% EtOH, 50\% xylene, and 10\% blood (data not shown). For repeatability and reproducibility, the measured number for the 3 concentrations of positive control was 240 (10 days $\times 2$ runs/day $\times 4$ replicates $\times 3$ lots $)$. As shown in Table 2, the CV for intra- and inter-assay variability ranged from 0.6 to $2.5 \%$ and 1.2 to $2.5 \%$, respectively, which were all $<3 \%$. The intra-laboratory reproducibility results at cutoff concentration (about 1 copy) over time were $96.4 \%(\kappa=0.96,95 \% \mathrm{CI}, 0.926-0.985)$. Based on the experimental results, we suggest that this assay may have stable results.

\section{Detection of PCMV Using Conventional PCR, Nested PCR, and One-Tube Nested Real-Time PCR Methods in Clinical Samples}

To evaluate the performance of one-tube nested real-time PCR assay, a total of 127 clinical samples, including lung tissues ( $n$ $=37,29.1 \%)$, whole bloods $(n=30,23.6 \%)$, serums $(n=$ $30,23.6 \%)$, and feces $(n=30,23.6 \%)$, were used. The results were compared with those of conventional PCR (Figure 3A) and nested PCR (Figure 3B). Of the 127 clinical samples, 49 (38.6\%) samples were positive for PCMV, while 78 (61.4\%) samples were negative as detected by one-tube nested real-time PCR. On the other hand, $16(12.6 \%)$ and 30 (23.6\%) were detected by conventional PCR and nested PCR, respectively (Table 3 ). All clinical samples showed positive IC signals, and the $\mathrm{C}_{\mathrm{T}}$ values of the 49 positive and 81 negative samples ranged from 17.6 to 22.5 (mean 20.6, SD \pm 1 ) and 17.7 to 22.5 (mean 20.9 , SD \pm 0.8 ), respectively. In addition, the $\mathrm{C}_{\mathrm{T}}$ values of PCMV-positive samples ranged from 14 to 28.8 (mean 22.8, $\mathrm{SD} \pm 4.1$ ). In a pilot study, we investigated detection for PCMV infection in 10 organs (lung, liver, pancreas, spleen, kidney, brain, heart, small intestine, nasal concha, and tonsil) of 6 pigs. As a result, the organs with the most prevalent PCMV detected were lung, spleen, and nasal concha (100\%), followed by liver, small intestine, and tonsil (83.3\%), kidney, heart, and pancreas $(66.7 \%)$, and brain (50\%), respectively (data not shown).
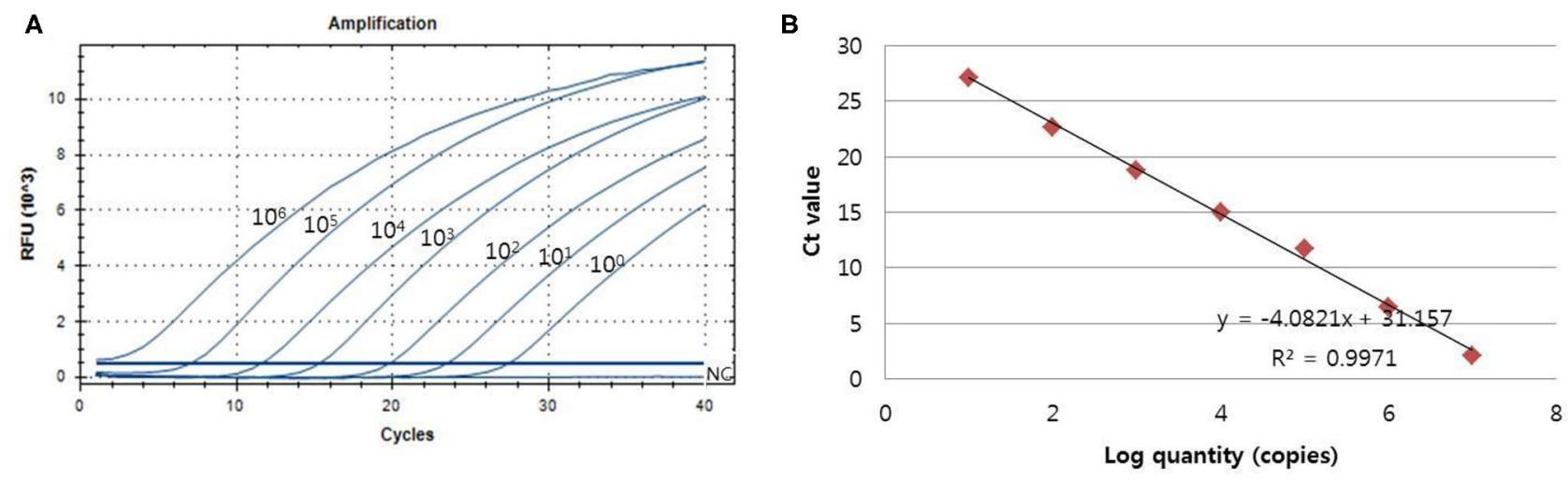

FIGURE 2 | The detection limit of the one-tube nested real-time PCR assay was evaluated using 10-fold serial diluted samples. Serially diluted PCMV control DNA ranging from $10^{6}$ copies to 1 copy per reaction were used to determine the detection limit of the one-tube nested real-time PCR assay. In the one-tube nested real-time PCR assay, the amplification curve of the specific probe (A) for detecting PCMV is shown. The overall detection limit of this assay for the PCMV ranged from approximately 1 copy DNA per reaction. $\mathrm{C}_{\mathrm{T}}$ was plotted against the input of the quantity of PCMV DNA (repeated 20 times). The linearity (B) was generated by plotting the log quantity of PCMV DNA vs. the corresponding $\mathrm{C}_{\mathrm{T}}$ value, and the coefficients of determination of the linear regression were 0.997 with a slope of -4.082 . The fluorescence intensity is displayed on the $\mathrm{Y}$-axis $\left(R^{2}=\right.$ reporter signal/passive reference signal). RFU, relative fluorescence unit; $R^{2}$, fluorescence units. 
TABLE 1 | Analytical specificity of the one-tube nested real-time PCR assay to detect PCMV with 40 strains.

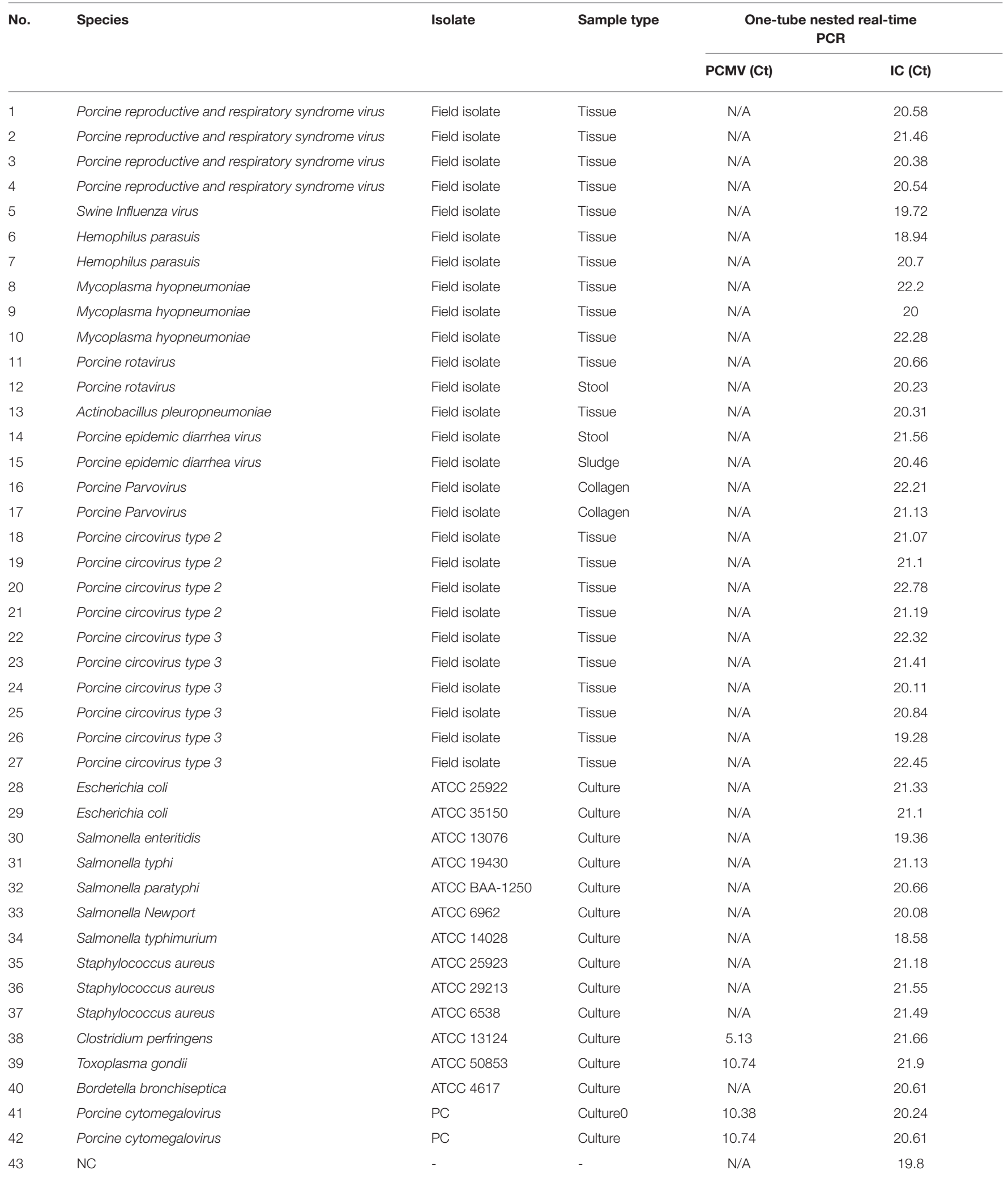

ATCC, American Type Culture Collection; PCMV, porcine cytomegalovirus. 
TABLE 2 | Results of intra- and inter-assay for repeatability and reproducibility analysis.

\begin{tabular}{|c|c|c|c|c|c|c|c|c|c|c|c|c|c|}
\hline \multirow[t]{3}{*}{ Copies/ $/ \mu \ell$} & \multirow[t]{3}{*}{$N$} & \multirow[b]{3}{*}{$\mathbf{C}_{\mathrm{T}}$ avg } & \multirow{3}{*}{$\begin{array}{l}\text { Total } \\
\text { SD }\end{array}$} & \multirow[b]{3}{*}{$\mathrm{CV}(\%)$} & \multirow{2}{*}{\multicolumn{3}{|c|}{$\begin{array}{l}\text { Intra-assay } \\
\text { Within-run }\end{array}$}} & \multicolumn{6}{|c|}{ Inter-assay } \\
\hline & & & & & & & & \multicolumn{3}{|c|}{ Between-run } & \multicolumn{3}{|c|}{ Between-day } \\
\hline & & & & & $\mathrm{C}_{\mathrm{T}}$ avg & SD & CV(\%) & $\mathbf{C}_{\mathrm{T}}$ avg & SD & CV(\%) & $\mathbf{C}_{\mathrm{T}}$ avg & SD & CV(\%) \\
\hline $10^{5}$ & 240 & 7.7 & 0.0 & 0.5 & 7.7 & 0.1 & 0.8 & 7.7 & 0.1 & 1.9 & 7.7 & 0.1 & 1.3 \\
\hline $10^{3}$ & 240 & 15.6 & 0.1 & 0.6 & 15.6 & 0.1 & 0.6 & 15.7 & 0.3 & 1.8 & 15.6 & 0.2 & 1.2 \\
\hline $10^{1}$ & 240 & 23.8 & 0.1 & 0.3 & 23.9 & 0.6 & 2.5 & 23.8 & 0.5 & 2.0 & 23.6 & 0.6 & 2.5 \\
\hline
\end{tabular}

$N$, test number of inter- and intra- assay; avg, average; $S D$, standard deviation; $C V$, coefficients of variation.

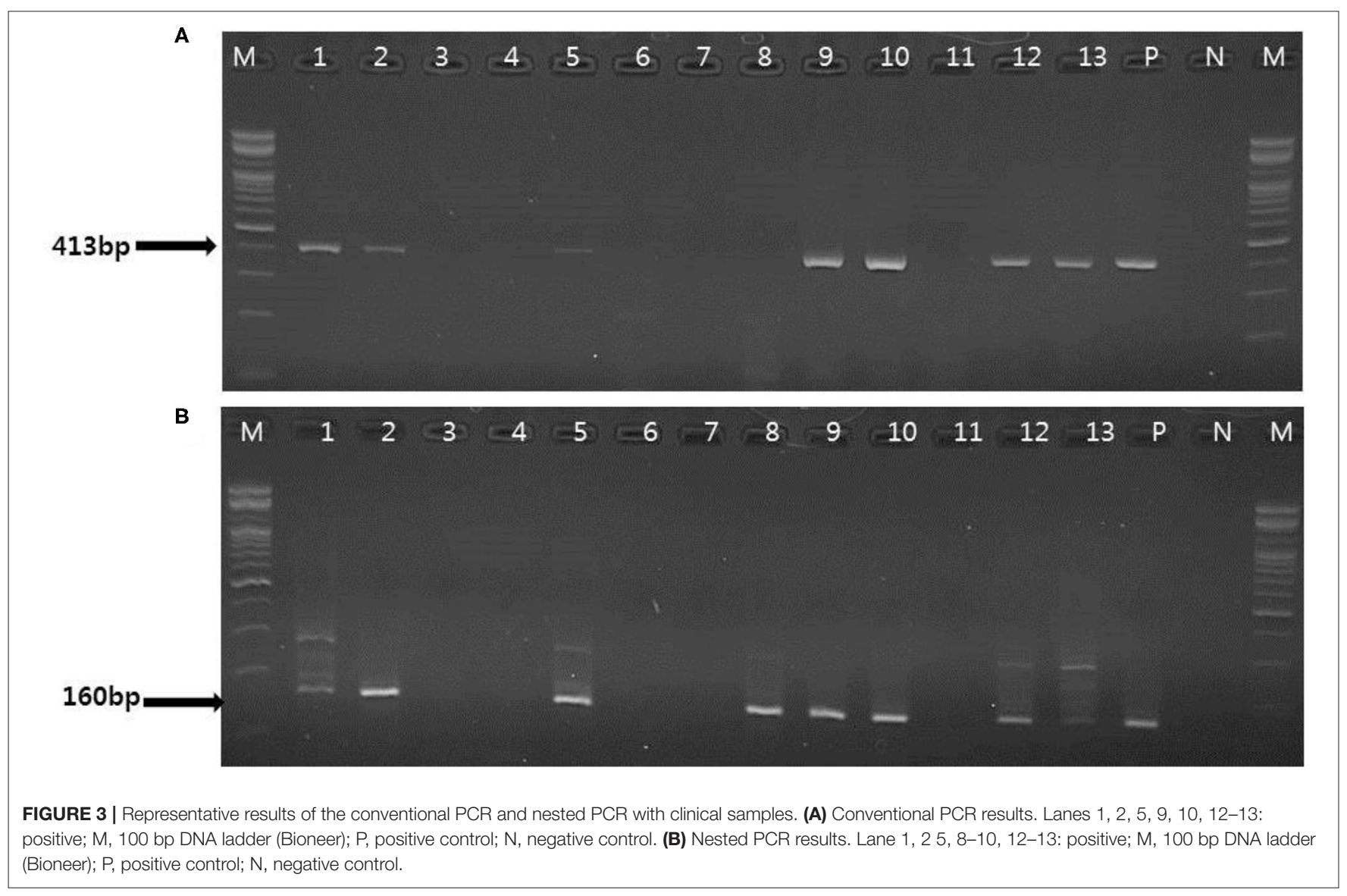

\section{Comparison of the Results Between the One-Tube Nested Real-Time PCR Assay and Sequence Analysis for the Detection of PCMV in Clinical Samples}

To confirm the results obtained from the one-tube nested realtime PCR assay, sequence analysis was performed using the same clinical samples. All 49 samples detected as PCMV-positive by one-tube nested PCR assay were consistent with the sequencing results. Our study showed that nested PCR had a higher positive rate than conventional PCR (23.6\% vs. $12.6 \%)$, but the one-tube nested real-time PCR assay (38.6\%) was more sensitive than the other two methods. The agreement rate between one-tube nested real-time PCR assay and conventional PCR or nested PCR was $74 \%(95 \%$ CI $0.654-0.813, p<0.001)$ and $85 \%(95 \%$ CI $0.776-0.907, p<0.001$ ), respectively (Table 4 ). In addition, the agreement rate of the one-tube nested real-time PCR assay and sequence analysis was $100 \%$ (95\% CI 0.976-1.000, $p<$ 0.001). Using sequence analysis, the sensitivity, specificity, and positive and negative predictive values of PCMV results by onetube nested real-time PCR assay were $100 \%(n=49,95 \%$ CI $0.947-1.000, p<0.001), 100 \%(n=78,95 \%$ CI $0.959-1.000, p$ $<0.001$ ), $100 \%$ (95\% CI $0.947-1.000, p<0.001), 100 \%(95 \%$ CI $0.959-1.000, p<0.001$ ), respectively. All PCMV-positive samples in conventional PCR or nested PCR methods were also positive in the one-tube nested real-time PCR assay. The 
TABLE 3 | Detection of PCMV DNA in 127 clinical samples suspected of PCMV infection using the conventional PCR, nested PCR, and one-tube nested real-time PCR assay.

\begin{tabular}{|c|c|c|c|c|c|c|c|c|c|}
\hline \multirow[t]{3}{*}{ Sample } & \multirow{3}{*}{$\begin{array}{l}\text { Total no. (\%) } \\
\text { of samples }\end{array}$} & \multicolumn{8}{|c|}{ Detection of PCMV, no. (\%) of isolates } \\
\hline & & \multicolumn{2}{|c|}{ Conventional PCR } & \multicolumn{2}{|c|}{ Nested PCR } & \multicolumn{4}{|c|}{ One-tube nested real-time PCR } \\
\hline & & Positive (\%) & Negative (\%) & Positive (\%) & Negative (\%) & Positive (\%) & Negative (\%) & $\begin{array}{c}\text { IC ranged } C_{T} \text { value } \\
(\text { mean } \pm S D)\end{array}$ & $\begin{array}{c}P C M V \text { ranged } C_{T} \\
\text { value (mean } \pm S D \text { ) }\end{array}$ \\
\hline Tissue & $37(29.1)$ & $16(43.2)$ & $21(56.8)$ & $25(67.6)$ & $12(32.4)$ & $32(86.5)$ & $5(13.5)$ & $17.6-22.1(20.5 \pm 0.9)$ & $14-27.3(21.1 \pm 3.9)$ \\
\hline Blood & $30(23.6)$ & $0(0)$ & $30(100)$ & $1(3.3)$ & $29(96.7)$ & $6(20)$ & $24(80)$ & $19.3-21.7(21.1 \pm 0.5)$ & $23.1-28.1(26.6 \pm 1.8)$ \\
\hline Serum & $30(23.6)$ & $0(0)$ & $30(100)$ & $2(6.7)$ & $28(93.3)$ & $6(20)$ & $24(80)$ & $20.5-22.5(21.6 \pm 0.5)$ & $20-28.5(21.6 \pm 0.5)$ \\
\hline Feces & $30(23.6)$ & $0(0)$ & $30(100)$ & $2(6.7)$ & $28(93.3)$ & $5(16.7)$ & $25(83.3)$ & $17.7-21.2(20.1 \pm 0.9)$ & $25.4-28.8(27.3 \pm 1.4)$ \\
\hline Total & $127(100)$ & $16(12.6)$ & $111(87.4)$ & $30(23.6)$ & $97(76.4)$ & $49(38.6)$ & $78(61.4)$ & $17.6-22.5(20.8 \pm 0.9)$ & $14-28.8(22.8 \pm 4.1)$ \\
\hline
\end{tabular}

PCMV, porcine cytomegalovirus; IC, internal control; SD, standard deviation.

TABLE 4 | Clinical sensitivity and specificity between the one-tube nested real-time PCR assay and conventional PCR, nested PCR, and sequence analysis methods stratified by PCMV suspected samples.

\begin{tabular}{|c|c|c|c|c|c|c|c|c|}
\hline \multirow[t]{2}{*}{$\begin{array}{l}\text { Molecular } \\
\text { assays }\end{array}$} & \multicolumn{2}{|c|}{$\begin{array}{l}\text { One-tube nested } \\
\text { real-time PCR }\end{array}$} & \multirow[t]{2}{*}{$\begin{array}{c}\text { Sensitivity, \% (n) } \\
(95 \% \mathrm{Cl})\end{array}$} & \multirow[t]{2}{*}{$\begin{array}{l}\text { Specificity, \% (n) } \\
(95 \% \mathrm{Cl})\end{array}$} & \multirow[t]{2}{*}{$\begin{array}{l}\text { PPV, \% (n) } \\
(95 \% \mathrm{Cl})\end{array}$} & \multirow[t]{2}{*}{$\begin{array}{l}\text { NPV, \% (n) } \\
\text { (95\% Cl) }\end{array}$} & \multirow[t]{2}{*}{$\begin{array}{c}\text { Agreement, \% (n) } \\
(95 \% \mathrm{Cl})\end{array}$} & \multirow[t]{2}{*}{$\begin{array}{c}\kappa \text { coefficient } \\
(95 \% \mathrm{Cl})\end{array}$} \\
\hline & Positive & Negative & & & & & & \\
\hline \multicolumn{9}{|c|}{ Conventional PCR } \\
\hline Positive & 16 & 0 & $\begin{array}{c}32.7(16 / 49) \\
(0.199-0.475)\end{array}$ & $\begin{array}{c}100(78 / 78) \\
(0.959-1.000)\end{array}$ & $\begin{array}{c}100(16 / 16) \\
(0.829-1.000)\end{array}$ & $\begin{array}{l}70.3(78 / 111) \\
(0.608-0.785)\end{array}$ & $\begin{array}{c}74(94 / 127) \\
(0.654-0.813)\end{array}$ & $\begin{array}{c}0.373 \\
(0.1893-0.5573)\end{array}$ \\
\hline Negative & 33 & 78 & & & & & & \\
\hline \multicolumn{9}{|c|}{ Nested PCR } \\
\hline Positive & 30 & 0 & $\begin{array}{c}61.2(30 / 49) \\
(0.462-0.748)\end{array}$ & $\begin{array}{c}100(78 / 78) \\
(0.959-1.000)\end{array}$ & $\begin{array}{c}100(30 / 30) \\
(0.905-1.000)\end{array}$ & $\begin{array}{c}80.4(78 / 97) \\
(0.711-0.877)\end{array}$ & $\begin{array}{l}85(108 / 127) \\
(0.776-0.907)\end{array}$ & $\begin{array}{c}0.659 \\
(0.518-0.800)\end{array}$ \\
\hline Negative & 19 & 78 & & & & & & \\
\hline \multicolumn{9}{|c|}{ Sequence analysis } \\
\hline Positive & 49 & 0 & $\begin{array}{c}100(49 / 49) \\
(0.947-1.000)\end{array}$ & $\begin{array}{c}100(78 / 78) \\
(0.959-1.000)\end{array}$ & $\begin{array}{c}100(49 / 49) \\
(0.947-1.000)\end{array}$ & $\begin{array}{c}100(78 / 78) \\
(0.959-1.000)\end{array}$ & $\begin{array}{l}100(127 / 127) \\
(0.976-1.000)\end{array}$ & $1(0.963-1.000)$ \\
\hline Negative & 0 & 78 & & & & & & \\
\hline
\end{tabular}

PPV, positive predictive value; NPV, negative predictive value; 95\% Cl, 95\% confidence interval.

phylogenetic tree was constructed using Phylogeny.fr software (19) after alignment of the 49 sequenced results. The 49 sequences obtained from direct sequence analysis of clinical samples were found that $69.4 \%(n=34)$ in the FJ01 strain (Groups A; accession no. MG696113) groups and $30.6 \%(n=15)$ in the B6 strain groups (Groups B; accession no. AF268039) were similar (Figure 4).

\section{DISCUSSION}

Pigs are frequently infected with PCMV, but infected adult animals do not always show symptoms of disease. Even though the virus remains latent, it can be transmitted the virus to anyone who receives a swine transplantation. Recently, pig-to-nonhuman-primate xenotransplantation have shown that transplant survival rates are 2-3 time lower when donor pigs were infected with PCMV (4). Therefore, highly sensitive methods are needed to select PCMV-free pigs and to screen for xenografts. The purpose of this study was to evaluate the analytical performance and clinical efficacy of newly developed high-sensitivity one-tube nested real-time PCR assay, taking advantage of conventional PCR and nested PCR for fast and accurate detection based on the DNA polymerase gene of PCMV. One-tube nested realtime PCR is a simple and sensitive method for the detection and identification of PCMV through sequential amplification of the DNA polymerase gene sequence of PCMV in a single tube (20). One-tube nested real-time PCR is about 100 times more sensitive than conventional PCR or nested PCR. Our results are consistent with previous reports indicated that nested PCR improved sensitivity significantly compared to conventional PCR, mostly due to two sequential amplification steps of the target gene (21-23). In addition, one-tube nested real-time 


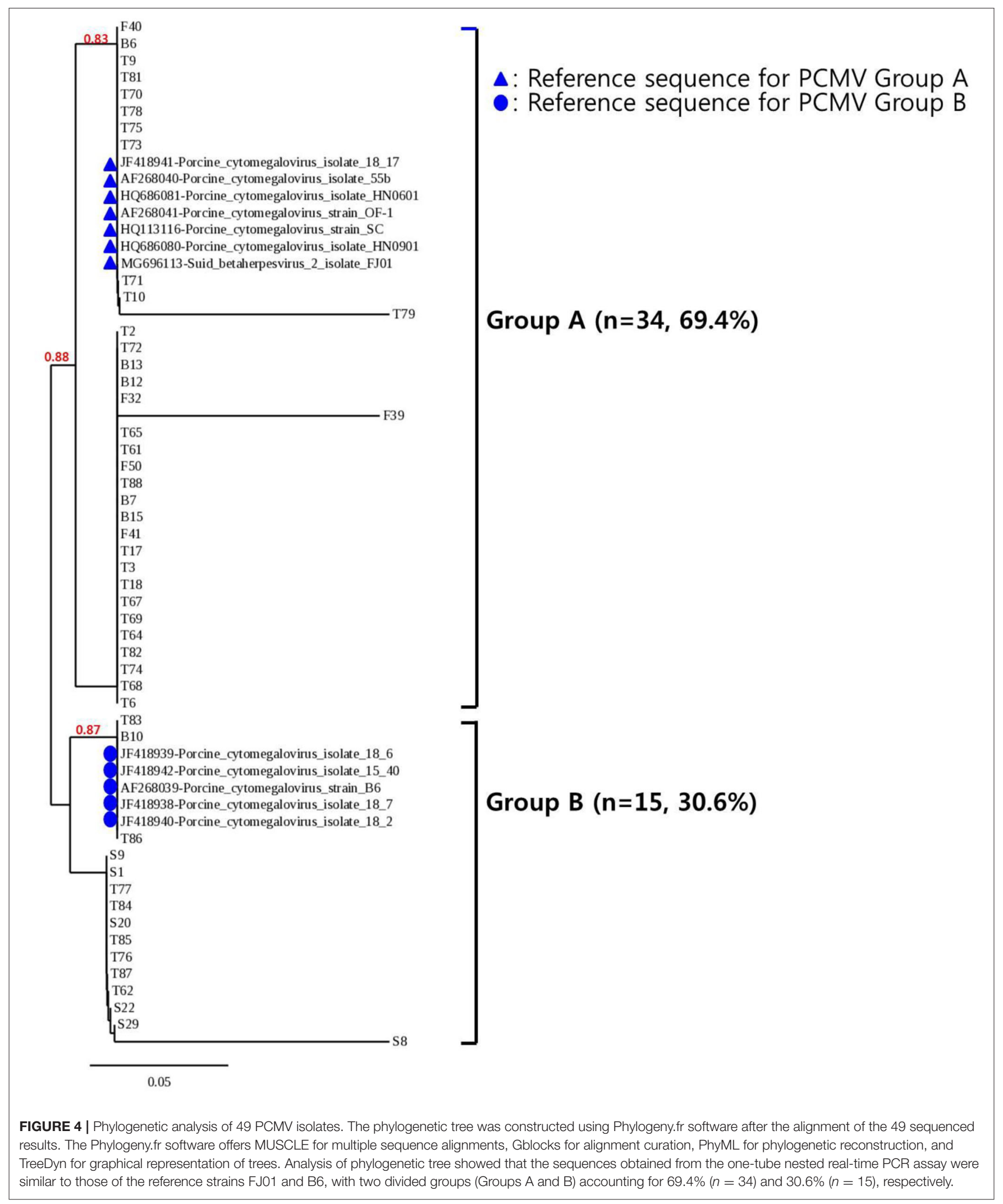


PCR has the same advantages as conventional real-time PCR, including ease, rapidity (turnaround time of $1.5 \mathrm{~h}$ ), accuracy, low risk of cross-contamination due to sequential reactions in a single tube, reproducibility, and high-throughput capabilities allows quick screening of multiple samples $(24,25)$. Moreover, the development of fluorescence-based real-time monitoring allows PCR to be a quantitative method, and PCR amplification or quantification was performed in the same reaction tube to reduce possible errors. Owing to its high sensitivity, one-tube nested real-time PCR has been proposed as an excellent method for determining various diseases $(24,25)$. In Korea, performance evaluation data such as sensitivity, specificity, reproducibility, and repeatability are required for product approval. To evaluate the performance and accuracy of the one-tube nested realtime PCR assay, the synthesized PCMV plasmid DNA was used as a reference standard, and $C_{T}$ values were repeatedly measured 20 times. The detection limit of the assay was determined to be 1 copy per reaction. The assay was tested using various strains, no cross-reactivity between strains was observed, and the presence of other samples in PCMV-infected strains was demonstrated to not affect the performance of the assay.

The DNA polymerase gene used in this study was proven to be a highly conserved sequence with no significant variation among several PCMV isolates (3), and showed a difference of 72.7 and $68.9 \%$ compared to that of human or mouse DNA polymerase genes, respectively. Nevertheless, the positive rate was high in samples from tissue other than sites. Thus, studies on areas with high PCMV infection in each organ should be conducted to gain further insights into xenotransplantation.

\section{REFERENCES}

1. Cooper DKC, Gaston R, Eckhoff D, Ladowski J, Yamamoto T, Wang L, et al. Xenotransplantation-the current status and prospects. Br Med Bull. (2018) 125:5-14. doi: 10.1093/bmb/ldx043

2. Kaufman CL, Bhutiani N, Ramirez A, Tien HY, Palazzo MD, Galvis E, et al. Current status of vascularized composite allotransplantation. Am Surg. (2019) 85:631-37. doi: 10.1177/000313481908500628

3. Chen R, Chen Q, Wu X, Che Y, Wang C, Wang L, et al. Development of a TaqMan based real-time fluorescent quantitative PCR assay for detection of porcine cytomegalovirus in semen. Biomed Res Int. (2020) 2020:5673145. doi: 10.1155/2020/5673145

4. Morozov VA, Plotzki E, Rotem A, Barkai U, Denner J. Extended microbiological characterization of Göttingen minipigs: porcine cytomegalovirus and other viruses. Xenotransplantation. (2016) 23:490-96. doi: 10.1111/xen.12265

5. Denner J. The porcine virome and xenotransplantation. Virol J. (2017) 14:171. doi: 10.1186/s12985-017-0836-z

6. McGregor CGA, Byrne GW. Porcine to human heart transplantation: is clinical application now appropriate? J Immunol Res. (2017) 2017:2534653. doi: 10.1155/2017/2534653

7. Gu W, Zeng N, Zhou L, Ge X, Guo X, Yang H. Genomic organization and molecular characterization of porcine cytomegalovirus. Virology. (2014) 460-1:165-72. doi: 10.1016/j.virol.2014.05.014

8. Liu X, Xu Z, Zhu L, Liao S, Guo W. Transcriptome analysis of porcine thymus following porcine cytomegalovirus infection. PLoS ONE. (2014) 9:e113921. doi: 10.1371/journal.pone.0113921

\section{CONCLUSIONS}

The one-tube nested real-time PCR assay generally showed high agreement and specificity with sequence analysis. This assay is a fast, accurate, and convenient tool for simultaneously detecting the presence of PCMV infection in many samples. Therefore, using the newly developed molecular diagnostic assay in PCMV screening can help detect the most important disease, while reducing false-positives or false-negatives. It is also likely to be used as a sensitive and specific tool for early detection and diagnosis of PCMV infection.

\section{DATA AVAILABILITY STATEMENT}

The datasets presented in this study can be found in the GenBank with accession code AF268039.

\section{AUTHOR CONTRIBUTIONS}

$\mathrm{H}-\mathrm{yW}$ performed evaluation of the experiments, analyzed the data, and drafted the manuscript. JS and SS provided clinical samples and clinical information. KC and $\mathrm{HK}$ revised the manuscript. All authors have read and approved the final manuscript.

\section{FUNDING}

This research was supported by Revitalization of medical convergence materials industry (Project No: 10065728) from Ministry of Trade, Industry, and Energy and we appreciate this support.

9. Rayat GR, Gazda LS, Hawthorne WJ, Hering BJ, Hosking P, Matsumoto $\mathrm{S}$, et al. First update of the International Xenotransplantation Association consensus statement on conditions for undertaking clinical trials of porcine islet products in type 1 diabetes-Chapter 3: Porcine islet product manufacturing and release testing criteria. Xenotransplantation. (2016) 23:3845. doi: 10.1111/xen.12225

10. Hamel AL, Lin L, Sachvie C, Grudeski E, Nayar GP. PCR assay for detecting porcine cytomegalovirus. J Clin Microbiol. (1999) 37:37678. doi: 10.1128/JCM.37.11.3767-3768.1999

11. Fryer JF, Griffiths PD, Fishman JA, Emery VC, Clark DA. Quantitation of porcine cytomegalovirus in pig tissues by PCR. J Clin Microbiol. (2001) 39:1155-6. doi: 10.1128/JCM.39.3.1155-1156.2001

12. Morozov VA, Morozov AV, Denner J. New PCR diagnostic systems for the detection and quantification of porcine cytomegalovirus (PCMV). Arch Virol. (2016) 161:1159-68. doi: 10.1007/s00705-016-2765-3

13. Tajima T, Hironao T, Kajikawa T, Suzuki Y, Kawamura H. Detection of the antibodies against porcine cytomegalovirus from whole blood collected on the blood sampling paper. J Vet Med Sci. (1994) 56:18990. doi: 10.1292/jvms.56.189

14. Liu $X, Z$ hu L, Shi $X, X u Z$, Mei $M, X u ~ W$, et al. Indirectblocking ELISA for detecting antibodies against glycoprotein B (gB) of porcine cytomegalovirus (PCMV). J Virol Methods. (2012) 186:30-5. doi: 10.1016/j.jviromet.2012.08.024

15. Yang JL, Zhang SH, Liu ZH, Yang R, Huang Y, Wen M. Development and evaluation of a loop-mediated isothermal amplification assay for the rapid detection of porcine cytomegalovirus under field conditions. Virol J. (2012) 9:321. doi: 10.1186/1743-422X-9-321 
16. Plotzki E, Keller M, Ivanusic D, Denner J. A new Western blot assay for the detection of porcine cytomegalovirus (PCMV). J Immunol Methods. (2016) 437:37-42. doi: 10.1016/j.jim.2016.08.001

17. Morozov VA, Heinrichs G, Denner J. Effective detection of porcine cytomegalovirus using non-invasively taken samples from piglets. Viruses. (2017) 9:9. doi: 10.3390/v9010009

18. Sun SR, Ahmad K, Wu XB, Chen JS, Fu HY, Huang MT, et al. Development of quantitative real-time PCR assays for rapid and sensitive detection of two badnavirus species in sugarcane. Biomed Res Int. (2018) 2018:8678242. doi: 10.1155/2018/8678242

19. Dereeper A, Guignon V, Blanc G, Audic S, Buffet S, Chevenet F, et al. Phylogeny.fr: robust phylogenetic analysis for the non-specialist. Nucleic Acids Res. (2008) 36:465-9. doi: 10.1093/nar/gkn180

20. Choi Y, Jeon BY, Shim TS, Jin H, Cho SN, Lee H. Development of a highly sensitive one-tube nested real-time PCR for detecting Mycobacterium tuberculosis. Diagn Microbiol Infect Dis. (2014) 80:299303. doi: 10.1016/j.diagmicrobio.2014.08.009

21. Abrahão JS, Lima LS, Assis FL, Alves PA, Silva-Fernandes AT, Cota $\mathrm{MM}$, et al. Nested-multiplex PCR detection of Orthopoxvirus and Parapoxvirus directly from exanthematic clinical samples. Virol J. (2009) 6:140. doi: 10.1186/1743-422X-6-140

22. Llop P, Bonaterra A, Penalver J, Lopez MM. Development of a highly sensitive nested-PCR procedure using a single closed tube for detection of Erwinia amylovora in asymptomatic plant material. Appl Environ Microbiol. (2000) 66:2071-8. doi: 10.1128/AEM.66.5.2071-2078.2000
23. Morris J, Clover GR, Harju VA, Hugo SA, Henry CM. Development of a highly sensitive nested RT-PCR method for Beet necrotic yellow vein virus detection. J Virol Methods. (2001) 95:163-9. doi: 10.1016/S0166-0934(01)00308-1

24. Shen XX, Qiu FZ, Zhao HL, Yang MJ, Hong L, Xu ST, et al. A novel and highly sensitive real-time nested RT-PCR assay in a single closed tube for detection of enterovirus. Diagn Microbiol Infect Dis. (2018) 90:1815. doi: 10.1016/j.diagmicrobio.2017.11.015

25. Zhao L, Wang J, Li GX, Qiu FZ, Chen C, Zhao MC, et al. A highly sensitive 1-tube nested real-time RT-PCR assay using LNA-modified primers for detection of respiratory syncytial virus. Diagn Microbiol Infect Dis. (2019) 93:101-6. doi: 10.1016/j.diagmicrobio.2018.09.001

Conflict of Interest: All authors were employed by Optipharm, Inc.

The authors declare that the research was conducted in the absence of any other commercial or financial relationships that could be construed as a potential conflict of interest.

Copyright (c) 2020 Wang, Song, Shin, Choi and Kim. This is an open-access article distributed under the terms of the Creative Commons Attribution License (CC BY). The use, distribution or reproduction in other forums is permitted, provided the original author(s) and the copyright owner(s) are credited and that the original publication in this journal is cited, in accordance with accepted academic practice. No use, distribution or reproduction is permitted which does not comply with these terms. 